RASĀYAN J. Chem.

Vol. 11 | No. 4 |1643 - 1648| October - December | 2018 ISSN: 0974-1496 | e-ISSN: 0976-0083 | CODEN: RJCABP http://www.rasayanjournal.com http://www.rasayanjournal.co.in

\title{
SOLID DISPERSION OF USNIC ACID-PVP K30 AND EVALUATION OF ANTIOXIDANT ACTIVITY
}

\author{
Lili Fitriani, Eka Rismawati, Salman Umar and Erizal Zaini* \\ Department of Pharmaceutics, Faculty of Pharmacy, Andalas University, Padang, Indonesia \\ *E-mail : erizal@phar.unand.ac.id
}

\begin{abstract}
Usnic acid, a compound produced by Usnea sp, has been reported for anti-oxidant activity. However, the use of usnic acid is still finite due to poor solubility in water. One of the processes to increase the solubility is by preparing into solid dispersion using hydrophilic polymer. The aims of this study were to prepare usnic acid in solid dispersion using poly-vinyl-pyrrolidone (PVP) K30 and evaluate its antioxidant activity. Solid dispersions were prepared using spray and freeze-drying method at a ratio of usnic acid:PVP of 1:1 and 1:2(w/w). The physical mixture at the same ratio was prepared as a comparison. The morphology of solid dispersion, which was depicted in scanning electron microscopy (SEM) analysis, showed rod crystal for usnic acid; sphere particles for PVP K30 and spray dried powder; porous particles for freeze-dried powder, and usnic acid embedded on the surface of PVP K-30 for the physical mixture. The amount of usnic acid dissolved in water was determined using a UV-Vis spectrophotometer. Freeze dried usnic acid-PVP at ratio 1:2 showed the highest solubility which was about 20-fold compared to intact usnic acid. Antioxidant activity was determined using the 2,2-diphenyl-1-picrylhydrazyl (DPPH) method and gallic acid was used as the reference. The result of antioxidant activity test showed the inhibition concentration $50 \%\left(\mathrm{IC}_{50}\right)$ were 12.471 , 80.242 and $63.867 \mu \mathrm{g} / \mathrm{ml}$ for gallic acid, intact usnic acid and freeze-dried usnic acid at ratio 1:2, respectively. In conclusion, solid dispersion is able to increase the solubility of usnic acid and the antioxidant activity is in accordance with the solubility result.

Keywords: Usnic acid, solid dispersion, PVP K30, antioxidant activity, freeze drying, spray drying.

(c) RASĀYAN. All rights reserved

\section{INTRODUCTION}

Lichens, a symbiosis of fungi and algae, have the ability to survive in extreme circumstances particularly when they are exposed to ultra-violet radiation that can scavenge radicals in order to protect the thalli ${ }^{1}$. This ability leads to the potential activity of lichens as natural pro-oxidant and anti-oxidant. One of most major secondary metabolites produced by lichen species, such as Usnea sp, is usnic acid. Usnic acid has been reported for its pharmacological activities as antibacterial, antiviral, anti-protozoa, anti-inflammation, antipyretic, anti-proliferation, anti-tumor, and antioxidant ${ }^{2,3}$. However, these remarkable activities are still limited in used due to the physiochemical properties of a usnic acid, that is poorly soluble in water $(<0.01$ $\mathrm{g} / 100 \mathrm{ml} \mathrm{)^{4 }}$.Many studies have discussed some methods to improve the solubility of usnic acid including microencapsulation using PLGA $^{5}$, inclusion complex using cyxclodextrine ${ }^{6}$, micellar solution ${ }^{7}$, and milling process $^{8}$. Among the methods mentioned above, solid dispersion is one the most popular methods to modify the psychochemical property active ingredient by dispersing the drug in either sugar, hydrophilic polymer or surfactant ${ }^{9}$. Our previous study has elaborated preparation and characterization of usnic acid in HPMC ${ }^{10}$. The aims of this study were to prepare solid dispersion of usnic acid by two different methods, spray and freeze-drying using PVP K-30, in order to increase its solubility and to evaluate the antioxidant activity. The antioxidant activity was evaluated by using 2,2-diphenyl-1-picryl-hydrazyl-hydrate (DPPH) method, a relatively fast and easy technique to determine activity by spectrophotometry ${ }^{11}$.
\end{abstract}

\section{Materials}

\section{EXPERIMENTAL}

Usnic acid was isolated from Usnea sp as described in previous work ${ }^{8}$, PVP K-30 (Shin-Etsu Chemical, Japan), DPPH (Sigma Aldrich, the USA), gallic acid (Sigma Aldrich, the USA), ethanol p.a (Merck, Germany), and distilled water.

Rasayan J. Chem., 11(4), 1643-1648(2018)

http://dx.doi.org/10.31788/RJC.2018.1144076

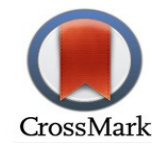




\section{Preparation of Solid Dispersion by Spray Drying Method}

Usnic acid and PVP K30 at ratio 1:1 and 1:2 (w/w) were dispersed in $100 \mathrm{ml}$ distilled water and the mixture was stirred prior and during the drying process. Spray dryer (BUCHI Mini spray dryer B-290, Switzerland) was set as follow: inlet temperature $120^{\circ} \mathrm{C}$ and outlet temperature $60^{\circ} \mathrm{C}$, flow $35 \mathrm{~m}^{3} /$ hour, and diameter of nozzle $0.7 \mathrm{~mm}$. The dried powder was collected from the particle collection chamber and kept in a desiccator.

\section{Preparation of Solid Dispersion by Freeze-Drying Method}

Usnic acid and PVP K-30 at the same ratio of the spray drying method were mixed and homogenized prior to the drying process. Liquid nitrogen was used to freeze the mixture. Freeze dryer (Christ Alpha 1-2 LD Plus, Germany) was set for primary drying at temperature $-20^{\circ} \mathrm{C}$ for 12 hours and continued to secondary drying at temperature $20^{\circ} \mathrm{C}$ for 12 hours. The dried powder was collected from the flask and kept in a desiccator.

\section{Preparation of Physical Mixture}

Usnic acid and PVP K-30 at the same amount of solid dispersion were mixed physically in a jar until the mixture was homogeneous and the mixed powder was then kept in a desiccator.

\section{Scanning Electron Microscope (SEM) Analysis}

The morphology analysis of intact usnic acid, intact PVP K-30, physical mixture and the solid dispersion was done using an SEM device (HITACHI type S-3400N, Japan) with the following condition: voltage 10 $\mathrm{kV}$ and current $12 \mathrm{~mA}$. A small amount of each sample was placed in a sample holder and sample was observed at several magnifications.

\section{Solubility Test}

The solubility of intact usnic acid, physical mixture and the solid dispersion was determined in free carbondioxide water. An excessive amount of sample was dispersed in water and shake in a water bath shaker at room temperature for 24 hours. The amount of usnic acid dissolved in water was measured spectrophotometry using UV-spectrophotometer (Shimadzu UV-1700, Japan) at a maximum wavelength of usnic acid in water $(283 \mathrm{~nm})$. All the samples were filtered using Whatman filter paper before measurement. All the solubility experiments were done triplicate.

\section{Free Radical Scavenging Activity}

Free radical scavenging activity was determined using DPPH method ${ }^{12-14}$. Gallic acid, which is known to have a strong antioxidant activity, was used as reference standard. $0.1 \mathrm{mM} \mathrm{DPPH}$ was added into a series concentration of the gallic acid solution, intact usnic acid, PVP K-30, physical mixture and solid dispersions. Each solution was incubated at room temperature $20^{\circ} \mathrm{C}$ for 30 minutes. The absorbance of samples and reference standard were measured at a maximum length of DPPH in ethanol using UVspectrophotometer (Shimadzu UV-1700, Japan) at $515.5 \mathrm{~nm}$. Scavenging activity was measured by following $\%$ inhibition equation:

$\%$ inhibition $=\frac{(\text { Abs DPPH }- \text { Abs Sample })}{A b s D P P H} \times 100 \%$

\section{Determination of $\mathbf{I C}_{50}$ Value}

$\mathrm{IC}_{50}$ value is defined as the minimum concentration of samples to inhibit $50 \%$ DPPH radical which was

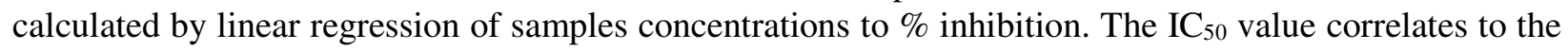
strong antioxidant activity.

\section{Data Analysis}

The data result of solubility and antioxidant activity was analyzed statistically by one way ANOVA with significance 95\% using SPSS 22.0. 


\section{RESULTS AND DISCUSSION}

Solid dispersion is one of many methods that has been used extensively to increase the solubility of poorly water-soluble drugs which can be prepared with a hydrophilic polymer, such as PVP K-30 ${ }^{15-17}$. In our previous study, solid dispersion of usnic acid with HPMC has increased the solubility of usnic acid about 5 times $^{10}$. In this study, PVP K-30 is used which is predicted to improve the solubility of usnic acid better than HMPC.

One of the most necessary characterization of solid dispersion is scanning electron microscopy (SEM). SEM is a prominent analysis to identify and observe the morphological changes of powder, particularly after modified by several processes. As can be seen in Fig.-1a, usnic acid crystal looks like rod and PVP K30 in Fig.-1b has a spherical shape. The physical mixture (ratio 1:2), Fig.-1c shows that usnic acid was embedded on the surface of PVP-K30. The spray dried usnic acid - PVP K-30 (ratio 1:2) depicts the spherical particles while freeze-dried (ratio 1:2) shows an irregular shape as see Fig.-1d and 1e. The differences on the morphology corresponded to the process utilized. The physical mixture applied lower energy compared to solid dispersions, which caused no change in the morphology of both usnic acid and PVP K-30. On contrary, solid dispersion by spray and freeze-drying techniques applied higher energy that contributed to morphology changes. Spray drying process used a nozzle which yields on spherical particles during the drying process caused by heat energy ${ }^{15}$. Meanwhile, freeze drying applied sublimation process on the drying process resulted in irregular shape and porous particles ${ }^{18}$. These changes are expected to influence the solubility of usnic acid.

The result of the solubility test is shown in Table-1. The solubility of usnic acid significantly increased after mixed with PVP K-30 $(\mathrm{p}<0.05)$. Moreover, the highest solubility was performed by freeze-dried at ratio $1: 2$. The impact of PVP K-30 in increasing the solubility has been discussed in many studies ${ }^{15-17}$. PVP K30 is a hydrophilic polymer that easily dispersed and dissolved in water ${ }^{19}$. The amount of PVP K-30 also influences the solubility, where ratio 1:2 for all prepared formulas had higher solubility compared to ratio $1: 1$. Therefore, the solubility of usnic acid in the physical mixture also improved significantly $(\mathrm{p}<0.05)$. In addition, the changes in morphology of usnic acid in solid dispersion preparation also affects the solubility. The spray dried particles had a spherical shape and smaller particle size than intact usnic acid which caused greater surface area ${ }^{15}$. Furthermore, the freeze-dried powder had small and big porous that also impact on the solubility due to more contact in water ${ }^{18}$.

Table-1: The Solubility Test Result

\begin{tabular}{l|l|l|l|l}
\hline $\begin{array}{l}\text { Usnic Acid (UA) } \\
(\mu \mathrm{g} / \mathrm{ml})\end{array}$ & $\begin{array}{l}\text { Ratio UA: PVP } \\
\mathrm{K}-30\end{array}$ & $\begin{array}{l}\text { Physical Mixture } \\
(\mu \mathrm{g} / \mathrm{ml})\end{array}$ & $\begin{array}{l}\text { Spray dried } \\
(\mu \mathrm{g} / \mathrm{ml})\end{array}$ & $\begin{array}{l}\text { Freeze Dried } \\
(\mu \mathrm{g} / \mathrm{ml})\end{array}$ \\
\hline \multirow{2}{*}{$55 \pm 0.02$} & $1: 1$ & $224 \pm 0.24$ & $376 \pm 0.47$ & $929 \pm 0.14$ \\
\cline { 2 - 5 } & $1: 2$ & $277 \pm 0.11$ & $577 \pm 0.09$ & $1,120 \pm 0.06$ \\
\hline
\end{tabular}

The improvement in solubility of usnic acid is also anticipated in anti-oxidant activity. Antioxidants are electron-giving compounds that have the ability to inactivating the oxidation reaction by radicals through preventing the formation of radicals or neutralizing existed radicals such as $\mathrm{DPPH}^{20}$. DPPH is a purple solution in ethanol when added a substance that has antioxidant properties, it will change into yellowish solution. This color change can be qualitative and quantitative parameters for determining anti-oxidant activity. The scavenging activity of gallic acid, usnic acid, PVP K-30, physical mixture (PM), spray dried (SD) and freeze-dried (FD) at different concentration is calculated by $\%$ inhibition as seen in Table-2.

The ability or the antioxidant strength of a substance is determined by the value of inhibition concentration $\left(\mathrm{IC}_{50}\right)$, which defines as the concentration of compound which can inhibit DPPH activity by $50 \%$. The lower the $\mathrm{IC}_{50}$ value of a compound, the stronger the antioxidant properties ${ }^{20}$. According to $\mathrm{IC}_{50}$ value, the antioxidant activity of a compound is classified as a strong activity if $\mathrm{IC}_{50} 10-50 \mathrm{ppm}$; moderate activity if $\mathrm{IC}_{50}>50-100 \mathrm{ppm}$; weak activity if $\mathrm{IC}_{50}>100-250 \mathrm{ppm}$; and no activity if $\mathrm{IC}_{50} 150-200 \mathrm{ppm}^{21}$. 
RASĀYAN $J$. Chem.

Vol. 11 | No. 4 |1643 - 1648| October - December | 2018
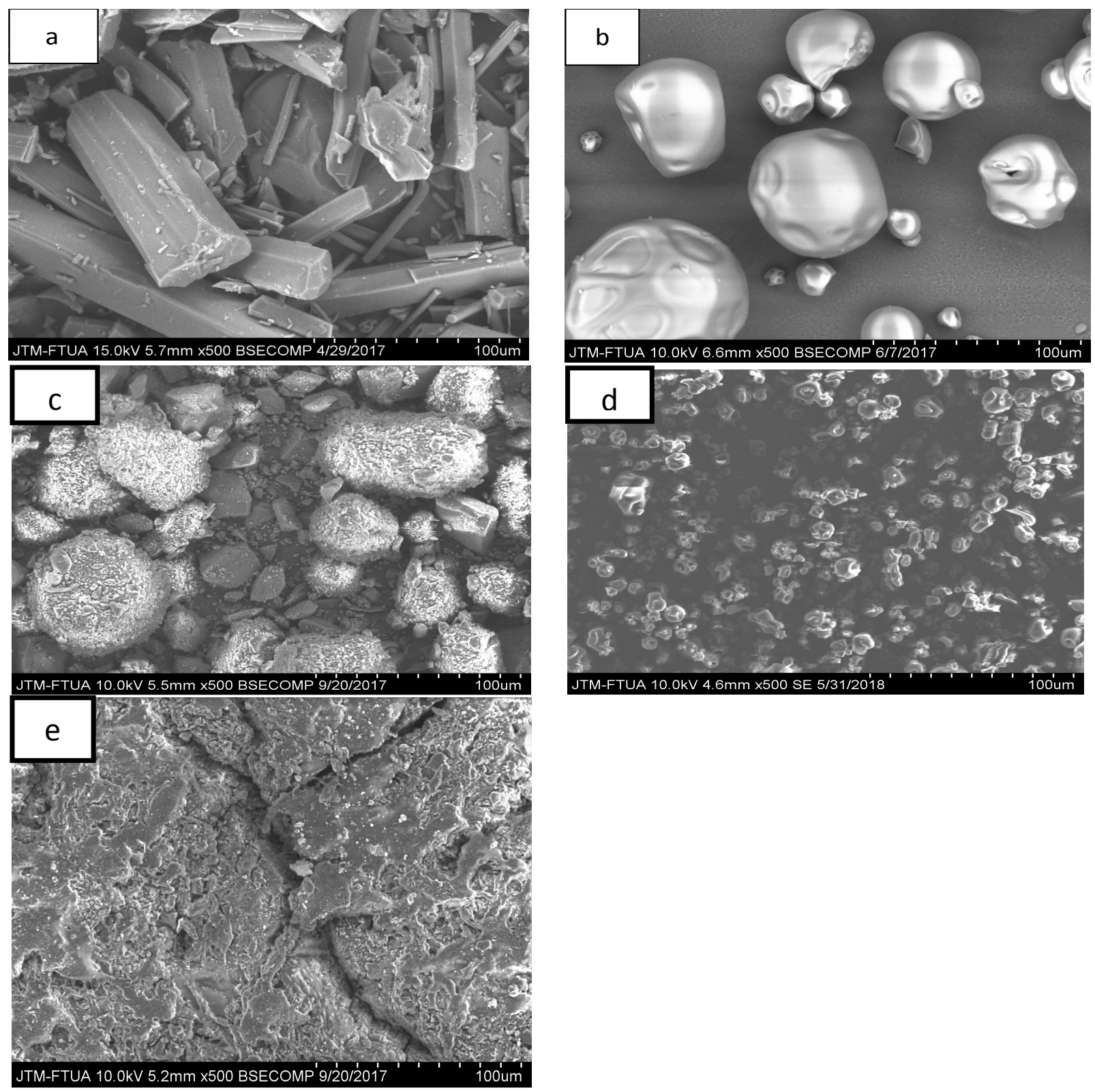

Fig.-1: SEM photos of (a) Usnic Acid, (b) PVP K-30, (c) Physical Mixture, (d) Solid Dispersion by Spray Dried, and (e) Solid Dispersion by Freeze-Dried.

Table-2: Percent (\%) Inhibition of each Sample at Different Concentrations

\begin{tabular}{|c|c|c|c|c|c|c|c|c|c|c|}
\hline \multicolumn{2}{|c|}{ Gallic Acid } & \multicolumn{9}{|c|}{$\%$ Inhibition } \\
\hline $\begin{array}{l}\text { Conc. } \\
\text { (ppm) }\end{array}$ & $\begin{array}{l}\% \\
\text { inhibition }\end{array}$ & $\begin{array}{l}\text { Conc. } \\
(\mathrm{ppm})\end{array}$ & PVP & $\begin{array}{l}\text { Usnic } \\
\text { acid }\end{array}$ & $\begin{array}{l}\text { PM } \\
(1: 1)\end{array}$ & $\begin{array}{l}\text { PM } \\
(1: 2)\end{array}$ & $\begin{array}{l}\text { SD } \\
(1: 1)\end{array}$ & $\begin{array}{l}\text { SD } \\
(1: 2)\end{array}$ & $\begin{array}{l}\text { FD } \\
(1: 1)\end{array}$ & $\begin{array}{l}\text { FD } \\
(1: 2)\end{array}$ \\
\hline 4 & 10.52 & 10 & 0 & 22.41 & 22.241 & 22.92 & 26.65 & 28.18 & 26.99 & 28.69 \\
\hline 5 & 13.24 & 30 & 0 & 30.89 & 30.73 & 31.40 & 35.48 & 36.67 & 35.82 & 37.18 \\
\hline 6 & 18.50 & 50 & 0 & 38.53 & 38.53 & 38.87 & 42.61 & 44.14 & 42.954 & 44.652 \\
\hline 8 & 28.86 & 70 & 0 & 45.33 & 46.01 & 46.34 & 50.424 & 51.61 & 50.764 & 52.122 \\
\hline 10 & 38.53 & 90 & 0 & 54.15 & 53.82 & 54.49 & 58.404 & 59.76 & 58.744 & 60.272 \\
\hline $\begin{array}{l}\mathrm{IC}_{50} \\
\mu \mathrm{g} / \mathrm{ml}\end{array}$ & 12.42 & $\begin{array}{l}\mathrm{IC}_{50} \\
\mu \mathrm{g} / \mathrm{ml}\end{array}$ & 0 & 80.24 & 79.91 & 78.68 & 68.57 & 68.17 & 67.70 & 63.87 \\
\hline
\end{tabular}




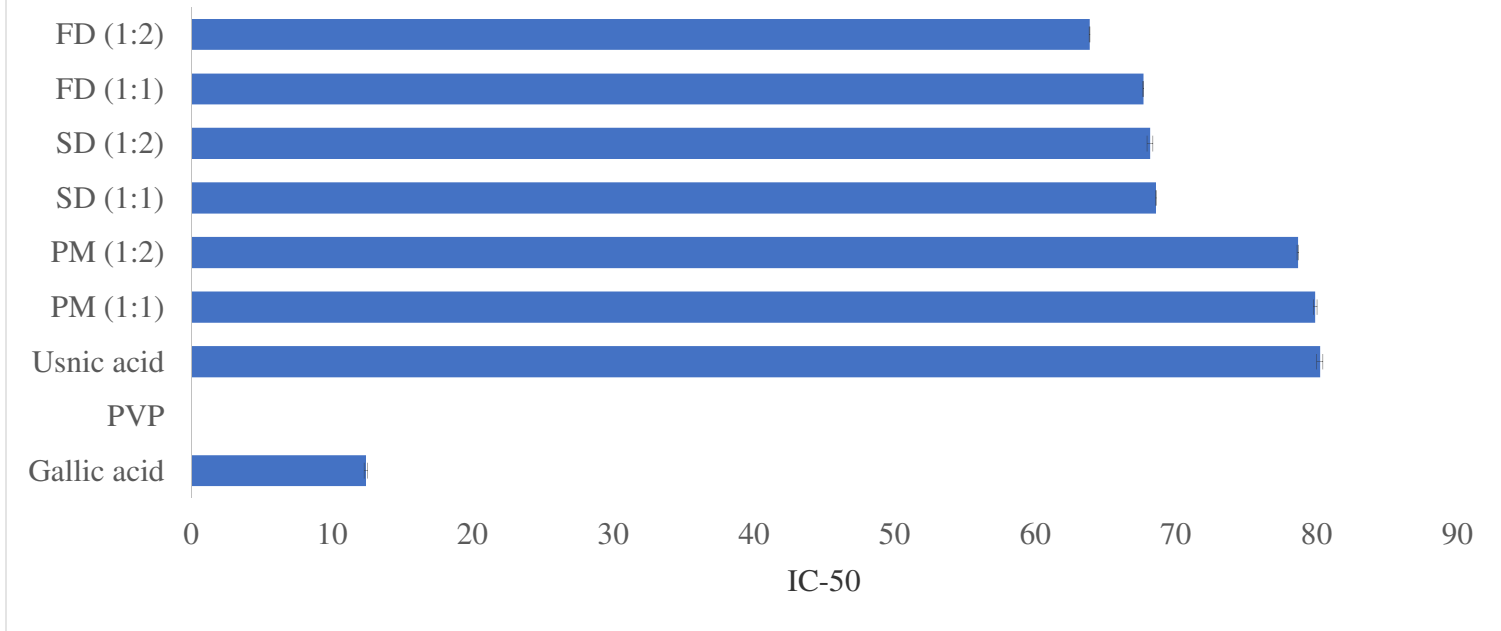

Fig.-2: $\mathrm{IC}_{50}$ Value of each Sample

The $\mathrm{IC}_{50}$ value of usnic acid, physical mixture and solid dispersions was in the range 50-100 ppm and included as a moderate antioxidant group, while gallic acid had a strong activity, as seen in Table 2 and Fig.-2.

The data of antioxidant activity test result was statistically proceed using one-way ANOVA in SPSS 22 program. There were significant differences $(\mathrm{p}<0.05)$ in $\mathrm{IC}_{50}$ values of intact materials to the physical mixture and solid dispersions. The enhancement of antioxidant activity is determined by the concentration of usnic acid dissolved. Freeze dried usnic acid had highest the solubility and in accordance to antioxidant activity. This result was also found in freeze-dried of Uncaria Tomentosa ${ }^{11}$.

\section{CONCLUSION}

The solid dispersion of usnic acid - PVP K-30, which prepared by spray and freeze drying methods, is able to modify the physicochemical properties that increase the solubility of usnic acid. Freeze dried powder has the highest solubility and antioxidant activity.

\section{ACKNOWLEDGMENT}

The authors would like to thank the Faculty of Pharmacy Andalas University for granting this research in 2018.

\section{REFERENCES}

1. C. Kohlhardt-Floehr, F. Boehm, S. Troppens, J. Lademann, T. G. Truscott, J. Photochem. Photobiol. $B$, 101(1), 97(2010), DOI: 10.1016/j.jphotobiol.2010.06.017

2. K. Ingolfsdottir, Phytochemistry, 61(7), 729(2002), DOI: 10.1016/S0031-9422(02)00383-7

3. A. A. S. Araujo, M. G. D. De Melo, T. K. Rabelo, P. S. Nunes. L. Santos L, Nat. Prod. Res., 29(23), 2167(2015), DOI: 10.1080/14786419.2015.1007455

4. M. J. O'Neil, The Merck Index - An Encyclopedia of Chemicals, Drugs, and Biologicals. 13th Edition, New Jesrsey, Merck and Co., Inc., 2001, p. 1762

5. R. M. Ribeiro-Costa, A. J. Alves, N. P. Santos, S. C. Nascimento, E. C. Gonçalves, N. H. Silva, ... and N. S. Santos-Magalhães, Journal of Microencapsulation, 21(4), 371(2004), DOI: 10.1080/02652040410001673919

6. V. Nikolić, M. Stanković, L. Nikolić, G. Nikolić, S. Ilić-Stojanović, M. Popsavin, ... and T. Kundaković, J. Incl. Phenom. Macrocycl. Chem., 76(1-2), 173(2013), DOI:10.1007/s10847-0120187-8

7. M. Lukáč, I. Prokipčák, I. Lacko, and F. Devínsky, Acta Fac. Pharm. Univ. Comen., 59(2), 36(2012), DOI:10.2478/v10219-012-0022-8 
8. E. Zaini, R. K. Nisak, R. D. Utami, L. Fitriani, and F. Ismed, Orient J. Chem., 33(6), 3031(2017), DOI: $10.13005 / \mathrm{ojc} / 330641$

9. T. Vasconcelos, B. Sarmento, and P. Costa, Drug Discov. Today, 12(23-24), 1068(2007), DOI: 10.1016/j.drudis.2007.09.005

10. L. Fitriani, I. Afriyanti, Afriyani, F. Ismed, E. Zaini. Orient J. Chem., 34(4)(2018), DOI: $10.13005 / \mathrm{ojc} / 3404048$

11. E. J. Garcia, T. L. C. Oldoni, S. M. D. Alencar, A. Reis, A. D. Loguercio, and R. H. M. Grande, Braz. Dent. J., 23(1), 22(2012), DOI:10.1590/S0103-64402012000100004

12. Ş. Bahçeci, N. Yıldırım, Ö. Gürsoy-Kol, S. Manap3, M. Beytur, and H. Yüksek, Rasayan J. Chem ., 9(3), 494. (2016).

13. P. Sugita, S. Arya, A. Ilmiawati and B. Arifin, Rasayan J. Chem.,10(3), 707(2017), DOI: 10.7324/RJC.2017.1031766

14. T. Okselni, A. Santoni, A. Dharma and M. Efdi, Rasayan J. Chem., 11(3), 1211(2018), DOI: 10.31788/RJC.2018.1133058

15. A. Paradkar, A. A. Ambike, B. K. Jadhav, and K. R. Mahadik, Int. J. Pharm., 271(1-2), 281(2004), DOI:10.1016/j.ijpharm.2003.11.014

16. A. Sharma, and C. P. Jain, Res. Pharm. Sci., 5(1), 49(2010)

17. F Frizon, J. de Oliveira Eloy, C. M. Donaduzzi, M. L, Mitsui, and J. M. Marchetti, Powder Technol., 235, 532(2013), DOI: 0.1016/j.powtec.2012.10.019

18. L. Fitriani, A. Haqi, and E. Zaini, J. Adv. Pharm. Technol. Res., 7(3), 105, (2016), DOI: 10.4103/2231-4040.18459

19. R. C. Rowe, P. J. Sheskey, and M.E. Quinn, Handbook of Pharmaceutical Excipients (Vol. 6). Pharmaceutical press, London, p. (2006), p.208

20. P. Molyneux, Songklanakarin, J. Sci. Technol., 26(2), 211 (2004)

21. S. Phongpaichit, J. Nikom, N. Rungjindamai, J. Sakayaroj, N. Hutadilok-Towatana, V. Rukachaisirikul, and K. Kirtikara, FEMS Immunol. Med. Microbiol., 51(3), 517(2007), DOI: 10.1111/j.1574-695X.2007.00331.x

[RJC-4076/2018] 